\section{Sir Frederick Macmillan, C.V.O.}

THE death of Sir Frederick Macmillan on June 1, at eighty-four years of age, ends a remarkable triumvirate in the history of the firm of Messrs. Macmillan and Co., Ltd., the publishers of NaTuRE ever since it was founded by them and Sir Norman Lockyer in November 1869. At that time the firm consisted of Mr. Alexander Macmillan, who died in 1896, and Mr. George Lillie Craik, who died ten years later. During their lifetime three other partners were admitted-Frederick Orridge Macmillan (1874), George Augustin Macmillan (1879) and Maurice Crawford Macmillan (1883).

By a most tragic set of circumstances, these three directors have all passed into silence within a period of three months. Mr. George Macmillan died on March 3, Mr. Maurice Macmillan on March 30, and on the day of his brother's funeral Sir Frederick slipped on the floor of his dressing-room and this accident led to his death on Monday last.

Sir Frederick Macmillan began his training as a publisher at Cambridge, and then went to New York where a branch house was opened in 1869. He was away for five years before returning to settle finally in the London office. In 1890 the New York branch was constituted on an independent basis as The Macmillan Co., and in $\mathbf{1 8 9 6}$ the London firm became Messrs. Macmillan and Co., Ltd. Sir Frederick Macmillan succeeded Mr. G. L. Craik as chairman of directors in 1905, and occupied that position until his death.

It is recorded in Mr. C. L. Graves's "Life and Letters of Alexander Macmillan" that "Sir Norman Lockyer had an absolutely free hand in reviewing books published by the firm, and never hesitated to criticise them adversely if he thought they deserved such treatment". To scientific readers it may seem unnecessary to refer to such editorial freedom; for reviewers pay little attention to the names of publishers, and would resent any suggestion as to the character of notices required of books submitted to them. It is, however, only just to testify that throughout the experience of the present Editor of NATURE, extending over forty-three years, neither Sir Frederick Macmillan, nor any other of the directors, has ever intervened in the editorial conduct of the journal. Only men with high ideals and broad outlook could take such an attitude towards a publication issued by them; and we gladly pay tribute to it.

NATURE would never have survived its early years if the publishers had regarded it merely as a business enterprise; for it was carried on for thirty-two years at a financial loss, and not until 1902 did the returns show a small profit. Sir Frederick Macmillan, who was the head of the firm for so many years, maintained this enlightened policy with unwavering support; and grateful acknowledgment may therefore be made appropriately in these columns of the important part he played in rendering the journal independent of considerations-financial and otherwise-which have often prevented other scientific periodicals from reaching maturity.
Sir Frederick Macmillan followed with close atten. tion the main developments of science recorded in these columns, and his personal friends included many workers in scientific fields of the past and present generations. $\mathrm{He}$ took an active part in $\mathrm{a}$ number of public and philanthropic organisations, among them being the Royal Literary Fund and the National Hospital for Diseases of the Nervous System, of which he was chairman of the Council of Management. He received the honour of knighthood from King Edward VII in 1909, when the jubilee building of this hospital was opened, and was created a C.V.O. in 1928. He will be sadly missed by a large circle of friends, and the memory of his fine figure and stimulating influence will long be cherished with affection by all who came into contact with him.

\section{Mr. H. G. G. Payne}

Mr. Humfrey Payne, director of the British School of Archæology at Athens, died on May 8 at the age of thirty-four years. Humfrey Gilbert Garth Payne was born in 1902, the son of Mr. E. J. Payne, fellow of University College, Oxford. $\mathrm{He}$ was educated at Westminster School and Christ Church, Oxford, holding an open scholarship of the latter foundation. He took first-class honours in both Classical Moderations and the Final School of Literæ Humaniores. After graduation, a research studentship of the University and a scholarship from his college enabled him to devote himself to Mediterranean archæology. For two years he was an assistant on the staff of the Ashmolean Museum, and then in 1929 became director of the British School of Archæology at Athens. This post he filled with the greatest competence. Although in the term of his directorship no such major excavation as had attracted widespread attention under some of his predecessors occupied the activities of the members, the work of the school gained a decision and directness of purpose which made for a high level of efficiency and scientific precision in archæological training and research.

Payne's personal achievement was greatest in the field of archaic art. His "Necrocorinthia" (1929) and his subsequent excavation of the important site of Perachora, opposite Corinth, placed him in the front rank of archæologists as a pioneer and authoritative interpreter of Corinthian art and culture in the archaic period. His premature death has broken a career which held out every promise of great achievement.

\section{WE regret to announce the following deaths:}

Prof. Francis Cavers, formerly professor of biology in University College, Southampton, author of wellknown text-books on elementary botany, on May 26.

Sir Archibald Denny, Bart., a well-known ship. builder and engineer, formerly president of the Institute of Marine Engineers and in 1918-27 chairman of the British Engineering Standards Association on May 29, aged seventy-six years. 